\title{
53. THE MAIN BASEMENT FEATURES RECOGNIZED IN THE NORTHERN PART OF THE NORTH ATLANTIC AREA ${ }^{1}$
}

\author{
J. P. Lefort, Groupe Armoricain d'Étude Structurale des Socles, Institut de Géologie, Rennes, France²
}

\begin{abstract}
The basement of the western European and eastern Canadian shelves is underlain in the northwest by metamorphosed terrains predating the late Precambrian; in the southeast, Cadomian deformations are widespread. These cratonic regions were broken up by the opening of two oceans during Paleozoic time. Remnants of Paleozoic ocean crust are now preserved in the sutures of the Iapetus and Theic oceans.

Later deformations, related to the collision between Laurussia and Gondwanaland, resulted in the development of three shear belts, oriented east to west, between middle and late Carboniferous time. Just before the Mesozoic opening of the North Atlantic, a large dextral shear belt developed between Labrador and the Bay of Biscay, crosscutting all the previously developed structures.
\end{abstract}

\section{INTRODUCTION}

It has often been said by marine geologists that transatlantic basement correlations will represent the ultimate stage in the investigation of the continental margins, and many geologists believe that a good knowledge of the Cenozoic and Mesozoic shelf evolution is necessary to understand the deep basement structures. In fact, there are so many problems in arriving at a detailed comprehension of the post-Paleozoic cover that interpretation of the basement features seems always to be deferred to a later date. Furthermore, the existence of major strikeslip deformations-younger than the late Hercynian tectonism but older than the Mesozoic opening-which occur just at the poorly documented ocean-continent boundary, suggests that progressive restoration is probably not the correct way to reorganize the preopening basement pattern.

The recent discovery of listric faults on the continental margin of northwest Europe (de Charpal et al., 1978; Guennoc, 1978) is convincing evidence that even the best transatlantic fits are inaccurate in longitude; a precise quantification of the stretching of the continental crust (related to the listric tectonism) is necessary for an accurate preopening reconstruction. In addition, because of the dextral shears that developed after late Hercynian time (before the Early Jurassic rifting between the Bay of Biscay and the Labrador Sea [Kay, 1969; Lefort, 1973]), none of the proposed Triassic reconstructions is really adapted to the transatlantic basement correlations. Nevertheless, the second of those two handicaps can be partially mastered. To this purpose, a new class of fit has been developed, based mainly on Hercynian transatlantic markers (Lefort, 1980). Those markers, already mapped for the continental crust on both sides of the North Atlantic, can be followed offshore by

\footnotetext{
${ }^{1}$ Graciansky, P. C. de, Poag, C. W., et al., Init. Repts. DSDP, 80: Washington (U.S. Govt, Printing Office).

2 Address: Group Armoricain d’Étude Structurale des Socles, Inst. de Géologie, Campus de Beaulieu, 35042 Rennes Cedex, France.
}

their geophysical signatures beneath the shelves. Most of them date from the late Carboniferous and appear as east-west shear belts between latitudes of the Hercynian Front and the South Atlas Fault (Lefort and Haworth, 1978, 1981; Max and Lefort, in press).

The resulting fit is characterized by the following rotation poles (Lefort and Van der Voo, 1981):

\begin{tabular}{ccc}
\hline $\begin{array}{c}\text { Plate rotated with } \\
\text { respect to America }\end{array}$ & Pole position & $\begin{array}{c}\text { Angle of } \\
\text { rotation }\end{array}$ \\
\hline Europe & $89.1^{\circ} \mathrm{N}, 150.3^{\circ} \mathrm{E}$ & $29.0^{\circ}$ \\
Iberia & $68.1^{\circ} \mathrm{N}, 344.2^{\circ} \mathrm{E}$ & $53.3^{\circ}$ \\
Africa & $66.0^{\circ} \mathrm{N}, 346.6^{\circ} \mathrm{E}$ & $76.7^{\circ}$ \\
\hline
\end{tabular}

The latitudinal precision of this fit is probably better than a few tens of kilometers, but unfortunately-because there are no meridian or submeridian structures of this age-the longitudinal positions of the continents have the same inaccuracy as the other classical reconstructions. Because most of the older transatlantic structures are transverse with respect to the present North Atlantic orientation, however, such an inaccuracy will not affect the general basement pattern too much.

\section{THE MAIN PRECAMBRIAN FEATURES RECOGNIZED IN THE NORTH ATLANTIC AREA}

\section{The Grenville Front}

In Canada, the Grenville Front (Fig. 1) is the limit between the Grenville (850- to 1500 -m.y.-old orogeny) and Churchill (1550- to 2400-m.y. old) chelozones; it is bordered in the south by a continuous gravity low (Thomas, 1974), sometimes superimposed on a magnetic low (Stockwell et al., 1965). The front has been extended, using free-air gravity data, up to the Cartwright Arch (van der Linden and Srivastava, 1975). On the Rockall microcontinent (Scrutton, 1972), the geophysical and geological data (Roberts et al., 1972; Miller et al., 1973) suggest that Laxfordian terrains are separated from 
$\bar{\Xi}$

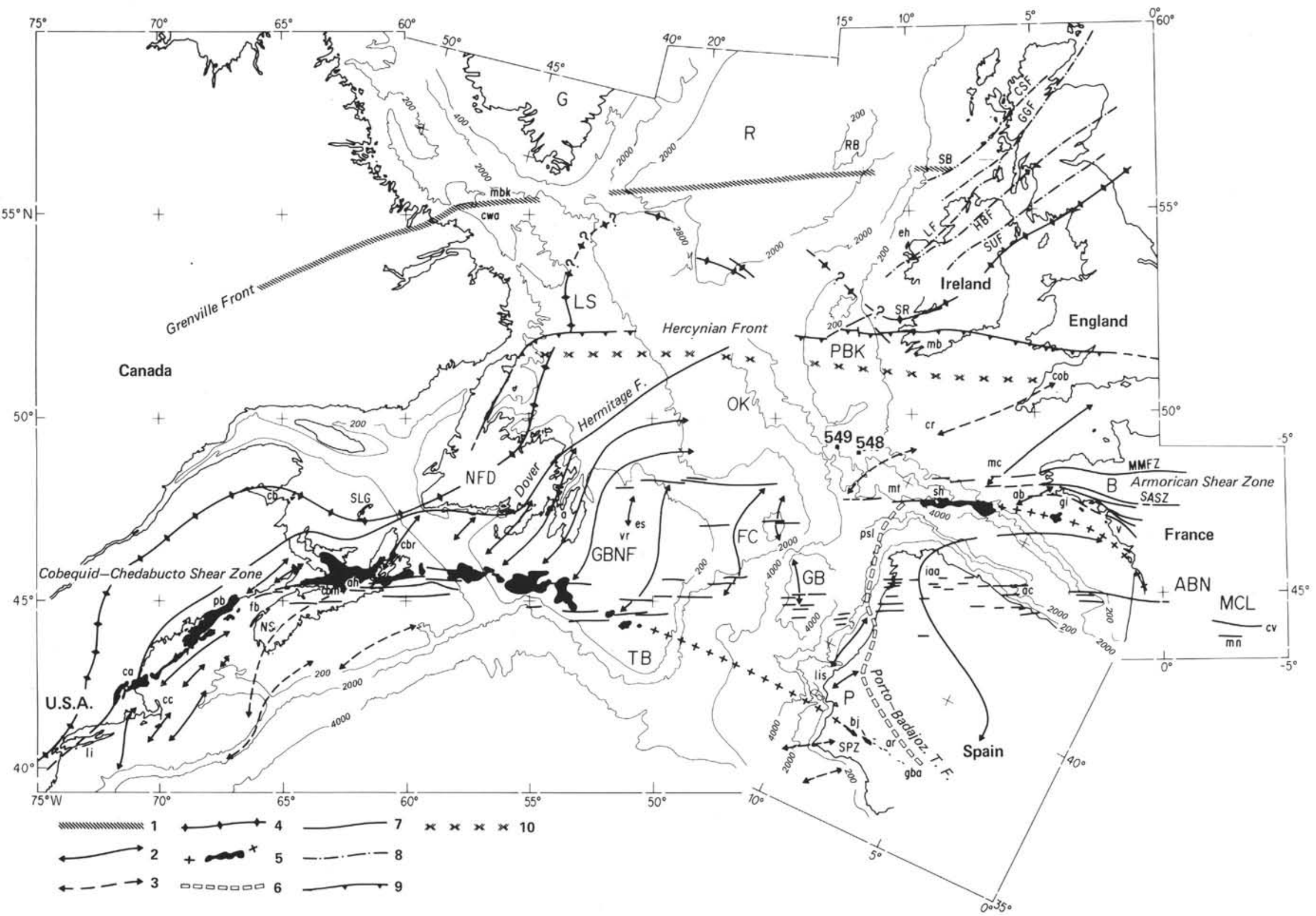


Figure 1. Preopening reconstruction of northern North Atlantic area (see text for criteria). Bathymetry in meters. The main basement features of the North Atlantic shelves (numbers refer to key at bottom of figure): 1 = Grenville Front; $2=$ Precambrian ridges; $3=$ Paleozoic ridges; $4=$ suture of the Iapetus Ocean; $5=$ suture of the Theic Ocean (magnetic bodies are represented in black); 6 = Petite Sole-Porto-Badajoz Paleozoic Transform Fault; 7 = late Paleozoic strike-slip faulting in France, Spain, and Canada; $8=$ middle to late Paleozoic strike-slip faulting in Scotland and Ireland; $9=$ Hercynian Front; $10=$ Carboniferous Basin.
$\mathrm{a}=$ Avalon
$\mathrm{ab}=$ Audierne Bay
$\mathrm{ABN}=$ Aquitaine Basin
ac $=$ Aviles Canyon
$\mathrm{ah}=$ Antigonish Highlands
ar $=$ Aracens
$\mathrm{B}=$ Brittany
bj $=$ Beja
$\mathrm{ca}=$ Cape Ann
$\mathrm{cb}=$ Chaleur Bay
$\mathrm{cbm}=$ Cobequid Mountain
$\mathrm{cbr}=$ Cape Breton
cob $=$ Cornwall Basin
$\mathrm{cc}=$ Cape Cod
$\mathrm{cr}=$ Cornubian Ridge

\author{
CSF $=$ Camasunary Fault \\ $\mathrm{cv}=$ Cevennes \\ cwa $=$ Cartwright Arch \\ eh $=$ Erris Head \\ es $=$ Eastern Shoals \\ $\mathrm{fb}=$ Fundy Bay \\ $\mathrm{C}=$ Flemish Cape \\ $\mathrm{G}=$ Greenland \\ $\mathrm{GB}=$ Galicia Bank \\ gba $=$ Guadalquivir Basin \\ GGF $=$ Great Glen Fault \\ gi $=$ Groix Island \\ $\mathrm{HBF}=$ Highland Boundary Fault \\ iaa $=$ Ibero-Armorican arc \\ $L E F=$ Leannan Fault
}

\author{
$\mathrm{li}=$ Long Island Sound \\ lis $=$ Lisbon \\ LS $=$ Labrador Shelf \\ $\mathrm{mb}=$ Munster Basin \\ mbk = Makkovik Bank \\ $\mathrm{mc}=$ Mid-Channel Ridge \\ MCL $=$ Massif Central \\ tour Fracture Zone \\ $\mathrm{mn}=$ Montagne Noire \\ $\mathrm{mt}=$ Meriadzek Terrace \\ NFD $=$ Newfoundland \\ NS $=$ Nova Scotia \\ $\mathrm{P}=$ Portugal \\ $\mathrm{pb}=$ Passamaquoddy Bay \\ $\mathrm{PBK}=$ Porcupine Bank
}

\section{psl $=$ Petite Sole lineamen \\ $\mathrm{R}=$ Rockall microcontinen}

$\mathrm{RB}=$ Rockall Bank

SASZ = South Armorican Shear Zone

SB $=$ Stanton Bank

sh $=$ Shamrock Canyon

SLG $=$ Gulf of St. Lawrence

SPZ $=$ South Portuguese Zone

$\mathrm{SR}=$ Shannon River

SUF $=$ Southern Upland Fault

$\mathrm{TB}=$ Tail of the Bank

$\mathrm{vr}=$ Virgin Rocks 
Grenvillian outcrops by an east-west gravity lineation (Roberts, 1970). The proposed boundary delineated here is not far from the limit already proposed by Roberts (1975).

When the Rockall Trough is closed (Le Pichon et al., 1977), the gravity low on the Rockall-Hatton Bank falls just in front of an east-west magnetic high located on the slope along the 56th parallel, which is already interpreted as the possible European extension of the front (Bailey, 1975). This magnetic anomaly can be extended eastward on the shelf (Gerard, 1979), where it is superimposed on a gravity low (Hydrographic Department, 1973). It is difficult, however, to distinguish whether this gravity low corresponds to the signature of the front or is related mainly to the narrow Mesozoic basin controlled by this basement disruption (Gerard, 1979). The postulated Grenville Front cannot be followed east of $8^{\circ} \mathrm{W}$, where it is interrupted by the seaward extension of the Camasunary-Skerryvore Transcurrent Fault (Bailey et al., 1975).

In this area, the closest geological controls are located on the Stanton Banks $\left(8^{\circ} 00^{\prime} \mathrm{W}, 56^{\circ} 10^{\prime} \mathrm{N}\right)$, where the Lewisian is known (Gerard and Boillot, 1977), and at Erris Head $\left(10.00^{\prime} \mathrm{W}, 54^{\circ} 15^{\prime} \mathrm{N}\right)$, where the Grenvillian crops out (Van Breemen et al., 1976). Note that the postulated course of the front is everywhere bordered by a morphological high, such as the Makkovik Bank on the Cartwright Arch, the northern high of the Rockall Bank on the Hatton-Rockall Plateau, or the Stanton Banks north of Ireland (Fig. 1).

\section{The Hadrynian Arches}

Gravity and magnetic mapping on the Grand Banks of Newfoundland (Haworth and McIntyre, 1975) showed a similarity between the disposition of deep structures of the Avalon Platform and the arcuate shape of the $\mathrm{Pa}$ leozoic orogen in Spain and Portugal (Haworth, 1977). Later, a more accurate study of the relationship between the magnetic and gravity anomalies and the exposed Appalachian structures of eastern Newfoundland gave good arguments for proposing a Precambrian age for the structures causing the anomalies (Haworth and Lefort, 1979). This proposed age was first based upon the facts (1) that the westernmost anomalies were cut obliquely at the Dover Fault-probably dating from the Hadrynian (latest Precambrian, post-Grenvillian) - which forms the western boundary of the Avalon Zone (Blackwood and Kennedy, 1975; Blackwood and O'Driscoll, 1976), and (2) that the onshore extensions of three of the lineated anomalies were shown to result from $\mathrm{Ha}$ drynian structures (Haworth, 1975). East of Newfoundland, no direct proof for a Precambrian age was found. It was suspected that although the general arcuate pattern in basement structure (as indicated by the anomalies) was Precambrian in origin, some magnetic and gravimetric features on the Grand Banks were probably younger, mimicking and thereby reinforcing the Precambrian basement trends.

In western Europe, the arcuate shape of the IberoArmorican trends has been the subject of much debate. Most authors believed it to be a Hercynian feature (Chou- bert, 1935; Carey, 1958; Anderson and Owen, 1968; Matte, 1968; Bard et al., 1971; Cogné, 1971; Matte and Ribeiro, 1975; Ries and Shackleton, 1976). It has been known for a long time, however, that the late Cambrian and early Paleozoic sedimentation was controlled by arcuate Precambrian ridges (Lötze, 1956; Matte, 1968; Vegas, 1978). More recently, paleomagnetic experiments on the Paleozoic series of the Spanish peninsula revealed without any ambiguity that the Ibero-Armorican arc was a secondary feature tightened during the Hercynian orogeny, the previous curvature being fully concentric with the Avalonian curvature (Lefort and Haworth, 1979; Perroud, 1980).

The structures in the following discussion have been recognized on the basis of geological and geophysical data from southern Brittany, northern Spain, and their adjacent continental margins.

Free-air gravity anomalies on the northern Iberian (Spanish) Shelf (Sibuet, 1972) show an alternation of highs and lows interpreted as representing a zone of highand low-density rocks. The alternation from $+30 \mathrm{mgal}$ in the west to $-30 \mathrm{mgal}$ in the center, to $+10 \mathrm{mgal}$ in the eastern part of the northwestern corner of the Iberian Shelf is disrupted only by the strong negative gravity anomaly caused by the deep Aviles Canyon at approximately $6^{\circ} 30^{\prime} \mathrm{W}$. Such an alternation is most clearly explained by the onshore data (Matte, 1968), where two basins of uppermost Precambrian and Paleozoic sedimentary rocks (the eastern one may contain $10 \mathrm{~km}$ of sediments) are separated by a ridge of metamorphic Precambrian rock with little or no Paleozoic cover. The existence of Hercynian granite bodies in the central zone increases the density contrast between the Precambrian ridge and the Paleozoic basins, and therefore emphasizes the gravity zoning. The geological zonation of the Spanish and Portuguese Precambrian arc may therefore be extended to the edge of the continental shelf north of Spain.

The free-air gravity map of the South Armorican Continental Shelf (Day and Williams, 1970; Sibuet, 1972) also exhibits a high-low-high alternation; this alternation has been interpreted to be related to underlying Paleozoic basins separated by a ridge of metamorphic rocks (Lefort, 1975), the same structural arrangement as noted on the northern Spanish margin.

The hypothesis that the Bay of Biscay was closed before the opening of the present Atlantic Ocean faces little objection these days, although there is continuing debate as to the correct location of Iberia with respect to France (Le Pichon et al., 1977). The reconstruction shown in Figure 1 is compatible with the detailed stratigraphic and paleontological correlation between the outer portion of the Ibero-Armorican arc on both sides of the Bay of Biscay (Henri et al., 1973), as well as with correlations between the late Hercynian fault patterns in France and Spain (Lefort and Haworth, 1978). On this reconstruction, the width of the gravity zones associated with the Armorican basins and those of Spain are in good agreement. It is therefore considered here that the structural zones south of Brittany, recognized by their geophysical expression, are the northeastward extensions 
of the zones recognized geologically and geophysically in northwestern Spain. This interpretation is reinforced by seismic refraction data. Velocities ranging between 5.1 and $5.8 \mathrm{~km} / \mathrm{s}$, observed in the interpreted basins, seem to be, as elsewhere in Brittany, characteristic of slightly metamorphosed upper Precambrian and Paleozoic rocks (Lefort, 1975). Deposition of those rocks was probably controlled by the higher-velocity ridge. The highest velocities, ranging between 6.3 and $6.5 \mathrm{~km} / \mathrm{s}$, are recorded between the basins, and are found to be related in Brittany to crystalline or highly metamorphosed rocks (Lefort and Haworth, 1979).

The northern Grand Banks area is characterized by continuous magnetic-anomaly and more or less fragmentary gravity-anomaly trends (Haworth and McIntyre, 1975). Three linear magnetic highs are offshore extensions of magnetic highs associated with Hadrynian volcanic rocks that outcrop on the Avalon Peninsula (Haworth, 1975; Haworth and Lefort, 1979). A fourth one lies close to Virgin Rocks and Eastern Shoals, where nonvolcanic Precambrian rocks were sampled (Lilly, 1966). The upper Hadrynian, dominantly subaerial volcanics of Avalon have been interpreted both in terms of volcanic arcs associated with a subduction zone (Hughes and Bruckner, 1971; Kennedy, 1976) and in terms of rifting preceding the opening of Iapetus (Schenk, 1971; Papezik, 1972; King, 1977). The magnetic expression of the volcanic rocks does not permit discrimination between these hypotheses.

On the inner part of the shelf, volcanic ridges whose seismic velocities range between 6.4 and $6.7 \mathrm{~km} / \mathrm{s}$ are characterized by gravity and magnetic highs. On the outer part of the shelf, concentric ridges, characterized by the same gravity and magnetic highs, were reactivated in Mesozoic time, and now form the cores of horsts which probably controlled Mesozoic and Cenozoic deposition.

On the eastern and southern parts of Avalon Peninsula, the thickening of the sequence of Hadrynian sedimentary rocks (Williams and King, 1976) correlates with a reduction in the gravity and magnetic fields. The northeastward extension of this low coincides with the 5.9$\mathrm{km} / \mathrm{s}$ layer observed on a refraction line. Such a velocity may therefore be characteristic of the Hadrynian sedimentary rocks lying between the higher-velocity volcanic highs.

It is possible that some of the basins between the volcanic highs are also infilled by lower Paleozoic rocks. On the basis of seismic reflection profiling, Grant (1972) has suggested this explanation for a gravity and magnetic low immediately east of the Avalon Peninsula.

If one compares the geophysical expression and geological interpretation of each of the different types of sinuous trends identified in Figure 1, one point is immediately evident: the Precambrian ridges in Europe have a different expression from those in Canada. This may be explained by the lack of large Hadrynian or Paleozoic basic intrusions in Brittany and northern Spain, compared with their extensive appearance in Newfoundland. Localized Hadrynian basic intrusions do exist in the European area (Den Tex and Floor, 1972; Cogné, 1974), but their volume is too small to produce effects of the magnitude seen in eastern Canada; the Precambrian ridges and those reactivated in Mesozoic time appear to have controlled even the post-Paleozoic sedimentation on both sides of the Atlantic (Lefort and Haworth, 1979).

\section{THE PALEOZOIC FEATURES RECOGNIZED IN THE NORTH ATLANTIC AREA}

\section{The Suture of the Iapetus Ocean}

The Iapetus Ocean, which separated Laurentia (Canada and Greenland) from the Avalon prong (the eastern Canadian Shelf and western central Europe), closed in middle Paleozoic time. The major structural trends of the eastern Appalachian border have been followed onshore by McKerrow and Cocks (1977) and Williams (1979), and offshore by Jacobi and Kristoffersen (1976). South of the Gulf of St. Lawrence, the structural zoning has been interpreted from gravity and magnetic data compiled by Haworth and McIntyre (1977); the course there of the suture of the Iapetus Ocean was first suggested by Haworth (1974) and then slightly modified by Haworth and Lefort (1979). North of Newfoundland, more recent gravity and magnetic data (Haworth, Grant, and Folinsbee, 1976; Haworth, Poole, et al., 1976) allow one to suggest a possible extension for this suture. It must be emphasized, however, that in this area the trajectory is only suggestive, since in Britain and Newfoundland the suture does not necessarily coincide with the magnetic expression of the ophiolitic layers, even when they give rise to a clear magnetic signature. Here, the course of the suture seems to veer north and then northwestward toward the southern Labrador Shelf. This has been interpreted more recently by Haworth and Jacobi (1983). Just north of Newfoundland, the suture shows a small dextral offset where it cuts across the western extension of the Hercynian Front (see discussion following). It is very difficult to link the suture at the northern termination of the Appalachian orogeny with its postulated course in Ireland (Stillman, 1979). There is very weak evidence from the magnetic lineations that the course swings northwestward between western Ireland and the Porcupine Bank (Max et al., 1982); it may follow a large magnetic low and a small variation in the wavelength of the anomalies west of the mouth of the Shannon River. How, though, can this be linked with the southern Labrador termination? There must be an undescribed curvature of the Appalachian axis to the south of the Rockall Bank. Such re-entrants of the Appalachian orogen are well known onshore in the south, and are typical of this mountain belt (Rankin, 1976). The only geophysical data supporting this interpretation, however, are the magnetic data collected by Vogt and Avery (1974) at the southwestern end of the Rockall Plateau. Although this bending of the belt is difficult to follow, it is the only way to link the Appalachian features with contemporaneous features known in the Caledonides of Europe, if the position of the suture mapped by Haworth and Jacobi (1983) is correct.

If we accept this interpretation, it must be noted that, in our reconstruction, the weak magnetic trends south of Rockall Plateau and north of Porcupine Bank show 
an offset of approximately a hundred kilometers just where the Dover Hermitage Fault and its seaward extension (Haworth, 1977) should link with the southwestern prolongation of the Great Glen Fault (Riddihough and Max, 1976) and associated fractures. Because these faults acted as sinistral shears (after the closure of the Iapetus Ocean) on both sides of the North Atlantic (for the Dover Fault it is a rejuvenation of the previous Hadrynian displacement; Blackwood and Kennedy, 1975; Hanmer, 1981; Max, 1978), it is highly possible that this apparent offset is a consequence of strike-slip tectonics rather than an artifact born of the lack of accurate geophysical data.

\section{The Suture between Laurussia and Gondwanaland}

Two crescent-shaped mafic belts south of Brittany and south of the Grand Banks of Newfoundland are linked by a large shear belt which strikes across Spain and Portugal. These structures are believed to represent two segments of the suture of the Theic Ocean, which once separated Laurussia from Gondwanaland (the term Theic Ocean is used, following Lefort [1983], instead of the terminology of McKerrow and Ziegler, 1972); the two structures are joined together by a fossil transform fault (Porto-Badajoz Fault). Those three features will be described in succession.

1. Recent studies of magmatic and metamorphic events between Hadrynian and Carboniferous time in southern Brittany suggest that the Hercynian mountain-building should be separated into two cycles (Cogné, 1977). An earlier cycle, extending from Silurian to late Devonian time, was probably the result of northward subduction beneath South Armorica (southern Brittany); a later cycle, extending from Dinantian to Westphalian time, involved an ensialic (intraplate) evolutionary cycle affecting the whole area.

Some of the Silurian and Devonian events are localized onshore in Brittany (Armorican Massif), and in the Massif Central (France). However, the conclusive data supporting the existence of a suture are based mainly on marine geology and offshore geophysical interpretations (Lefort, 1983).

The marine geophysical and marine geological data now available (Audren and Lefort, 1977; Lefort and Segoufin, 1978; Lefort et al., 1981) allow a more accurate location of the possible suture and support the following points:

A. The submerged blueschist outcrop located around Groix Island is probably not the ancient location of the South Armorican suture; the whole of the blueschist belt is now regarded as a flat-lying obduction sole or a klippe which was emplaced northward during Silurian or early Devonian time (Quinquis, 1980).

B. Marine studies have delineated the suture approximately $60 \mathrm{~km}$ to the south of Groix, where gravity and magnetic discontinuities display an arcuate belt which parallels the present coastline beneath the Mesozoic and Cenozoic cover (Lefort, 1979a).

C. This belt separates two different structural domains. The southwesternmost domain is characterized by gravity highs and lows trending east-west (Sibuet, 1972); these represent remnants of the Ibero-Armorican arc, which links with the Galician arc when the Bay of Biscay is closed. The airborne magnetic data show, after a second-derivative calculation (Horn et al., 1974), the same structural trends, which are cut in places by a late set of faults oriented $\mathrm{N} 130^{\circ}$ (Lefort, 1975).

To the north and east, the same magnetic data reveal the existence of structures which are parallel to the South Armorican orogen. Gravity data are sparse in this area, but they are sufficient to show that the alternation of "highs" and "lows" disappears on the Armorican side of the inferred suture. In general, the postulated suture, which is buried beneath the Mesozoic and Cenozoic cover, is characterized by a small volume of magnetic rocks.

The postulated suture, and associated mafic bodies (e.g., at $47^{\circ} \mathrm{N}, 4^{\circ} \mathrm{W}$ ), can be extended westward by an elongated magnetic anomaly (amplitude $120 \mathrm{nT}$ ) mapped between 6 and $10^{\circ} \mathrm{W}$; this anomaly terminates close to the Meriadzek Terrace $\left(10^{\circ} 30^{\prime} \mathrm{W}\right)$.

Even though it is at times parallel to the continental margin, this magnetic body cannot be considered in the west as an edge effect between the ocean crust and continental crust, for the following reasons: (1) the magnetic structure is an extension of a continental structure of the inner shelf (see the foregoing); (2) there is no equivalent edge effect south of Brittany; (3) the boundary between ocean crust and continental crust is located $90 \mathrm{~km}$ to the south (Guennoc, 1978).

2. The magnetic anomaly of the Meriadzec Terrace is interrupted by two faults, oriented $\mathrm{N} 40^{\circ} \mathrm{E}$, which are recognized in seismic reflection data (Guennoc, 1978). These faults are considered to be old features, rejuvenated during the Mesozoic North Atlantic opening. The $\mathrm{N} 40^{\circ}$ faults acted as transform directions for the contact between the present-day ocean crust and continental crust, indicating that they were probably preexisting (Lefort, 1979b).

The interruption of the South Armorican Paleozoic suture at Shamrock Canyon by two major faults near $10^{\circ} 30^{\prime} \mathrm{W}$ now explains why the previously described Precambrian and lower Paleozoic magnetic arcs on the Grand Banks of Newfoundland (Haworth and Lefort, 1979) are still intact along the 47 th parallel. In the following discussion, the faults which terminate the South Armorican trends (the transform origin of which will be discussed later) will be called the Petite Sole lineament, after the name of a bank located north of the Meriadzek Terrace. This lineament may be extended southward to the Spanish block.

When using the "fit" already cited, one can see the clear extension of the Petite Sole lineament into the Spanish Shelf. Adjacent to the N $40^{\circ}$ faults mapped on the Armorican margin, there is a deep furrow which is filled by Mesozoic and Cenozoic sediments. This inner basin, separating Spain from Galicia Bank, has been interpreted to be the result of Mesozoic rifting which developed along an old line of weakness (Auxietre and Dunand, 1978). The eastern limit of the Galician Basin links with the submerged end of the Porto-Badajoz-Cordoba Fault (Lefort et al., 1981). This fault, which extends between Porto and the Guadalquivir Basin, acted as a ma- 
jor structure during the entire Paleozoic history of Iberia. It is considered as an important boundary for the early Paleozoic faunas (Paris and Robardet, 1977), and separates the Centro-Iberian domain (with Armorican likeness) from the South Iberian domain (South Portuguese Zone).

3. Despite the gap which exists (as in every transatlantic "fit") between the Tail of the Banks and the South Portuguese Zone, it is possible to connect the gravity and magnetic anomalies existing in these two areas. In southern Portugal the absence of magnetic data in the east does not preclude this connection, since the geophysical data stop just where the Iberian mafic belt begins. This belt is made up of (1) gabbro-dioritic zone of Beja and (2) the Aracena complex. The former contains gabbros, basalts, and serpentinites with ophiolitic composition (Andrade, 1979), whereas the latter has felsic and mafic tuffs associated with layered amphibolites identical to abyssal tholeites (Bard, 1977; Bard and Moine, 1977). Both exposures occur in a narrow line which has been interpreted as a "geosuture" (Tamain, 1978). The mafic belt tends to link, beneath the Guadalquivir Basin, with the southern end of the Petite Sole-Cordoba Transform Fault. Near Beja, the intrusions are Devonian, whereas the volcanics of Aracena are pre-Silurian (Bard, 1977). None of these rocks, however, are considered as true ophiolites, and they do not show tectonites in their lowest parts.

The entire South Portuguese Zone has been interpreted as the location of a Devono-Carboniferous subduction zone dipping northeast (Bard, 1971; Carvalho, 1972; Bard et al., 1973; Vegas and Munoz, 1976). Although broadly convincing, this model must be modified to take into account recent geochemical analyses (Munha, 1979). In Munha's interpretation, the Iberian mafic belt probably results from back-arc crustal extension (Bard and Moine, 1977); the true suture must be looked for a few kilometers to the south, beneath the Carboniferous cover of the South Portuguese Zone.

The linear magnetic anomaly which faces the Portuguese mafic belt on the Grand Banks of Newfoundland has been called the Collector Anomaly (Haworth and McIntyre, 1975). This structure extends into Nova Scotia, where it has been interpreted as a suture (Poole, 1976). The calculated mafic body, which exists at depth, never crops out, and is probably not related to the Cobequid Mountains and Antigonish Highlands volcanics. Westward, the Collector Anomaly disappears beneath the Bay of Fundy, perhaps hidden below the thick sediments there (Belt, 1968). Moreover, Keppie (1977) concludes that the graben is the location of an old subduction zone.

Near Passamaquoddy Bay (U.S.A.), the thickness of the sediments decreases (Ballard and Uchupi, 1975), and mafic rocks that give rise to the Collector Anomaly are again exposed; farther south, down to Cape Ann, superimposed magnetic and gravity highs indicate a continuance of mafic rocks (Kane et al., 1972). This body is called the Bay of Maine igneous complex (Chapman, 1962); it is composed of volcanics (old andesites and rhyolites) of early Silurian to early Devonian origin and De- vonian gabbroic rocks (Gates, 1969). The Bay of Maine mafic complex is probably adjacent to a suture (Osberg, 1978): the geochemical relationships of some associated ultramafic-mafic rocks strongly suggest an ocean-crustal affinity and origin (Gaudette, 1980).

Thus, the same geophysical markers may be followed from south of Brittany to south of Iberia and south of the Maritimes. Apparently they are caused everywhere by Silurian or Ordovician volcanics associated with Devonian gabbros and diorites. True obducted ophiolites are not found in America, but a Paleozoic volcanic arc, developed on or adjacent to ocean crust, is known to be present. The best evidence suggesting that this body is the suture of the Theic ocean is, however, the recent paleomagnetic data for the gabbros of Beja (Portugal). Those rocks give an African pole for the late Devonian (Perroud et al., 1982). A few kilometers north of the gabbros, the Paleozoic sediments contain typical European faunas.

\section{The Late Hercynian Transatlantic Shear Belts}

After the collision between Laurussia and Gondwanaland, a series of intraplate deformations occurred; they constituted the Hercynian deformational episode. One of the chief events at that time was the appearance of large east-west shear belts which are now delineated on both sides of the North Atlantic. All of these acted as dextral transcurrent shear zones between middle and late Carboniferous time. Four shear belts are now known between the latitudes of southern Ireland and Morocco.

The Hercynian Front in Europe has been considered for years as a typical north-facing thrust, but new data (Max and Lefort, in press) suggest that it is associated in places with a dextral shear which developed at the northern margin of an upper Paleozoic basin with an eastwest trend. It is probable that the transition from lowintensity folding to overfolding and overthrusting or horizontal shearing depends on the position and shape of the southern edge of the northern pre-Variscan basement, which seems to be fairly shallow beneath southern Wales. In Ireland, the classical Hercynian Front runs approximately parallel to the northern side of the Munster Basin, which is quite steep in the western part of the island (Naylor and Sevastopulo, 1980). That is probably why the front is better expressed in that region. Although no basement core samples have been taken on Porcupine Bank, the basement features can be tentatively deduced from geophysical data. Porcupine Sea Bight has to be closed before any correlation can be achieved, in order to accommodate the magnetic striping recently mapped in the Bay of Biscay (Lefort and Max, in press); in this area, Porcupine Bank is now interpreted to have drifted slightly northwestward, following transform directions trending $\mathrm{N} 130^{\circ}$. Two main eastwest features are known on the bank. The southernmost zone at $52^{\circ}$ latitude, where seismic reflectors are known beneath the cover (Bailey, 1975b), probably represents the western extension of the axis of the Cornubian Ba$\sin$. The northernmost feature is an east-west lineated magnetic feature at $52^{\circ} 30^{\prime} \mathrm{N}$ (Riddihough and Max, 1976), although new magnetic data (Max et al., 1982) 
suggest that the feature might be more correctly located at $52^{\circ} 40 \mathrm{~N}$, where Lefort and Max (in press) tentatively delineated the location of the front. This linear feature correlates with the possible extension of the front west of Ireland. The line is more or less coincident with the $53^{\circ} \mathrm{N}$ flexure described by Bailey (1975a). I suggest that the northern line reflects the Hercynian Front (a shear or a thrust), and that the gravity and magnetic data a little farther south are related to the northern boundary of the basin in the east, already described.

Few geological and geophysical data are available for Orphan Knoll (Lefort and Haworth, in press), on the western side of the North Atlantic. The free-air gravityanomaly map of offshore eastern Canada (Shih in Keen and Hyndman, 1979) shows, however, a strong low caused by a thick Mesozoic basin, probably related to a basement feature, with a similar orientation, located just in front of the east-west Irish structures. South of the Labrador Shelf, a seismic reflection profile oriented parallel to the boundary between the ocean crust and the continental crust shows the same structural succession as in Cornwall: a 4570-m-thick basin filled with Visean and Namurian strata (Cutt and Laving, 1977) is interrupted in the north by a thrust boundary clearly seen on shallow seismic reflection records (Lefort and Haworth, in press). North of Newfoundland, the pattern of the fold axis recognized in the Mississippian and Pennsylvania strata trends north-south, but displays a dextral bending, which suggests that the north-facing thrusts in the area were associated with a general dextral transcurrent displacement.

The weak cleavage in the basement rock specimens of the Goban Spur does not provide any real constraint for the position of the Hercynian Front, since intense cleavage and Hercynian folding is known south of this position, as well as north of it in England and Ireland. Furthermore, the folding recorded north of Newfoundland in Carboniferous strata (Lefort and Haworth, in press), and the weak cleavage observed in some samples from wells on the Grand Banks of Newfoundland and the Labrador Continental Shelf, suggest that the Hercynian deformation does not die out at the western end of the European continental crust. Because the metamorphism in the samples is weak, it is clear that Sites 548 and 549 are probably north of the main Hercynian metamorphic belt of Europe, but south of the northern margin of important regional Hercynian deformation seen in Ireland.

The east-west Carboniferous shear belts delineated between Brittany, Spain, and the Grand Banks of Newfoundland (Lefort and Haworth, 1978) will now be described. Because of the dearth of good magnetic and gravimetric data for the Iberian Shelf, basement fractures were identified using seismic reflection data alone. The Mesozoic and Cenozoic faults in the area result only from the reactivation of basement faults (Groupe Galice, 1976; Lamboy, 1976).

Within Iberia (Spain and Portugal), several sets of wrench faults have been recognized, each with a distinct orientation (Arthaud and Matte, 1975). A few years ago, the pre-Mesozoic locations of Iberia and Galicia Bank were not well defined, and many slight variations from a basic rotation of a composite Iberia and Galicia Bank were proposed (see Choukroune et al., 1973). With a rotational closure of the Bay of Biscay by approximately $30^{\circ}$ and a southeastward shift in the location of Galicia Bank relative to Iberia (Le Pichon et al., 1977), one of the fault systems in Iberia and Galicia Bank becomes approximately parallel to the well-known east-west fault system west of France. This basic rotational closure has been slightly improved in longitude since the recognition of the geophysical zoning in the Ibero-Armorican arc (see the earlier discussion of the Hadrynian Arches).

Seismic (King and McLean, 1970, 1976; Grant, 1972, 1973, 1975), magnetic, and gravimetric data (numerous sources used by Haworth and McIntyre, 1976) have been employed to define a pattern of east-west fractures on the Grand Banks. Most of the faults have been defined by magnetic and gravity data, as described at the beginning of this section. Because of the possibility of misinterpreting the contoured data (Haworth and McIntyre, 1976), all north-south magnetic profiles were individually examined to justify each of the proposed fractures. Most of these fractures offset or interrupt southwesttrending magnetic zones that correlate with horsts composed of volcanic rocks of the Avalon Platform, Newfoundland (Haworth and Lefort, 1979).

The main east-west fractures and those oriented close to that direction show good general continuity between the onshore and offshore structures in Brittany, Spain, Portugal, and Nova Scotia. (The presentation has been simplified onshore in order to produce a homogeneous map.) In particular, two major belts of east-west fractures, each reasonably limited in width, can be seen. The first one, at the same latitude as the South Armorican Shear Zone (Cogné, 1960) and the Molene-Montcontour Fault (Chauris, 1969), continues westward to the east of Newfoundland just north of the 48th parallel. It does not appear to extend into Newfoundland itself. The other belt extends the Cobequid-Chedabucto Fault Zone (Webb, 1969) across the southern part of the Grand Banks, to Galicia Bank and northern Spain, and then to the Montagne Noire and Cevennes regions of southeastern France (Arthaud and Matte, 1975).

Without the information provided by the markers already recognized on the continental shelves, it might be suggested that the two major belts of the South Armorican Shear Zone and the Cobequid-Chedabucto Fault Zone were continuous in the late Paleozoic, but this would necessitate a southeastward shift of France and the British Isles by about $500 \mathrm{~km}$. Such movement does not permit complete late Paleozoic closure of the Atlantic north of $48^{\circ} \mathrm{N}$ (Srivastava, 1978).

The onshore fractures within the two major belts already cited are reputed to have originated in the Carboniferous (Cogné, 1960: Poole, 1976). In Nova Scotia, Brittany, the northwestern part of the Iberian Peninsula, and the Montagne Noire, the east-west fractures show dextral displacement. There is no indication of the direction of fault motion along the offshore fractures of the northern belt, but the offset of some seismic and mag- 


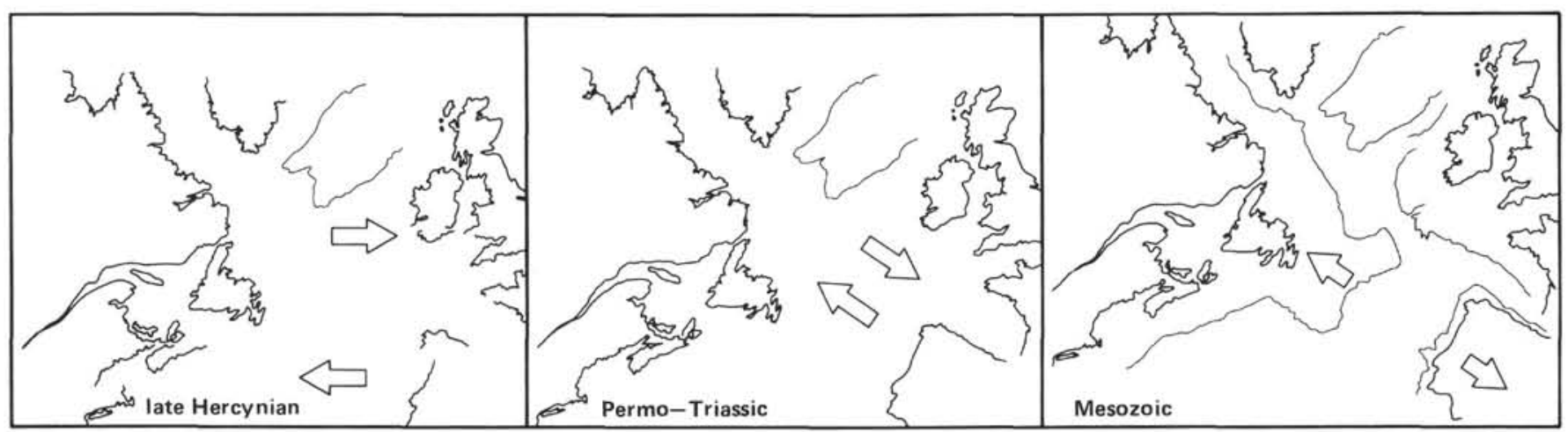

Figure 2. The last basement shearings before the actual North Atlantic opening.

netic features by fractures forming part of the southern belt on the Grand Banks and south of Galicia Bank suggest dextral movement.

The timing and distribution of the dextral shearing recognized on both sides of the present North Atlantic show that the Hercynian deformations were controlled overall by a shear regime which extended between the Hercynian Front and the South Atlas Fault. This particular regime was associated with limited sinistral displacements now well documented in places along the Appalachian belt. Both displacements resulted from the impingement on Laurussia (North America and Europe) of the West African craton (Lefort and Van der Voo, 1981).

\section{THE PREOPENING FEATURES RECOGNIZED ON THE ATLANTIC MARGINS}

It has been recognized for a few years that dextral offsets, caused by $\mathrm{N} 130^{\circ}$ strike-slip faults, have affected western Brittany (Cogné, 1960) and Vendée (Butel and Ters, 1952), as well as Cornwall (Dearman, 1963). This earliest set of faults crosscuts all the late Hercynian shears of Stephanian age, and is intruded by 190- to 205-m.y.-old dolerites (Leutwein et al., 1972; Dymond in Leutwein et al., 1972). Thus, this transcurrent movement developed after the Hercynian events and before the North Atlantic opening. This faulting is widespread offshore (Lefort, 1973, 1975; Vigneresse, 1978)-west of Brittany, west of Cornwall (Bott et al., 1958), and west of Ireland (Lefort and Max, in press)-and seems to concentrate just at the edge of the continental margin. This fault system is much more developed on the European margins than on the Grand Banks of Newfoundland and the Labrador Shelf (Haworth and Lefort, 1979; Lefort and Haworth, in press). On the shelves themselves offsets are seldom greater than a few hundreds or thousands of meters, but the displacements seem to increase toward the boundary between the ocean crust and the continental crust; this increasing displacement is the reason why a late Hercynian transatlantic fit has been preferred to a Triassic reconstruction for the North Atlantic area (see the Introduction). This fault system parallels the postulated Biscay Bay-Labrador fault system (Kay, 1969), which preceded the Mesozoic North Atlantic opening. Although sometimes disputed (Roberts et al., 1981), remnants of the shear belt are known onshore in Labrador (Krank, 1947), Greenland (Allaart, 1967), northern Spain (Parga, 1969), and France (Lefort, 1973). Because of the poor continuity of the trends which constitute this shear belt, however, it is not represented on Figure 1.

\section{SUMMARY}

The basement underlying the continental margin of the northern part of the North Atlantic is as old as the upper Hadrynian; this basement, however, incorporates much older terrains of Lewisian and Grenvillian age, in the north, as well as Pentevrian inliers in western Brittany. The oldest large-scale structures actually recognized are concentric arches, which are typical of the Cadomian orogeny between the Avalon Peninsula and western Europe. In the west and in the north, the suture of the Iapetus Ocean separates those terrains from Grenvillian and older outcrops of Laurentia (America and Greenland); in the south, the suture of the Theic Ocean separates the Cadomian area from Gondwanaland. The closure of the Iapetus Ocean generated the northern Appalachian belt in middle Paleozoic time, and the closure of the Theic Ocean was responsible for the development of the Appalachian and Hercynian orogenies.

Later, in the Carboniferous time, intraplate deformations accommodated the stress between Gondwanaland and Laurussia. This was responsible for a large dextral shear zone, $3000 \mathrm{~km}$ wide, which affected the earlier structures.

Further dextral shearing affected all basement structures between Labrador and the Bay of Biscay, just before the Mesozoic opening of the North Atlantic (Fig. 2).

\section{ACKNOWLEDGMENTS}

Many thanks are due the reviewers, M. F. Kane (U.S. Geological Survey), W. S. McKerrow (Oxford University), D. G. Roberts (British Petroleum), and R. A. Scrutton (University of Edinburgh), who helped me to improve this paper, although they do not necessarily share all of my opinions.

\section{REFERENCES}

Allaart, J. H., 1967. Basic and intermediate igneous activity and its relationships to the evaluation of Julianehäb granite, South Greenland. Medd. Gronland, 175:1-136.

Anderson, J. G. C., and Owen, T. R., 1968. The Structure of the British Isles: Oxford (Pergamon).

Andrade, A. A. S., 1979. Aspectos geoquimicos do Ofiolitoide de Beja. Com. Serv. Geol. Portugal, 64:39-48. 
Arthaud, F., and Matte, P., 1975. Les décrochements tardi-hercyniens du Sud-Ouest de l'Europe. Géométrie et essai de reconstitution des conditions de la déformation. Tectonophysics, 25:139-171.

Audren, C., and Lefort, J. P., 1977. Géologie du plateau continental sud-armoricain entre les îles de Glénan et de Noirmoutier. Implications géodynamiques. Bull. Soc. Geol. Fr. 7:395-404.

Auxietre, J. G., and Dunand, J. P., 1978. Géologie de la marge ouest ibérique (au Nord de $40^{\circ} \mathrm{N}$ ) [thesis]. University of Paris.

Bailey, R. J., 1975a. The geology of the Irish continental margin and some comparison with offshore eastern Canada. Can. Soc. Petrol. Geol., 4:313-340.

1975b. Sub-Cenozoic geology of the British continental margin (lat. $50^{\circ} \mathrm{N}$ to $57^{\circ} \mathrm{N}$ ) and the re-assembly of the North Atlantic late Paleozoic supercontinent. Geology, 3:591-594.

Bailey, R. J., Buckley, J. S., and Kielmas, M. M., 1975. Geomagnetic reconnaissance on the continental margin of the British Isles, between $54^{\circ}$ and $57^{\circ}$ N. J. Geol. Soc. London, 131:11-9.

Ballard, R. D., and Uchupi, E., 1975. Triassic rift structures in the Gulf of Maine. Am. Assoc. Petrol. Geol. Bull., 59:1041-1072.

Bard, J. P. 1971. Sur l'alternance des zones métamorphiques et granitiques dans le segment hercynian sud-ibérique; comparaison de la variabilité des caractères géotectoniques de ces zones avec les orogènes "orthotectoniques". Bolotin Geol. Min. 82:324-345. 1977. Signification tectonique des métatholeites d'affinité abyssale de la ceinture métamorphique de basse pression d'Aracena (Huelva, Espagne). Bull. Soc. Geol. Fr., 7:385-393.

Bard, J. P., Capdevila, R., and Matte, P., 1971. La structure de la chaîne hercynienne de la Meseta ibérique: Comparaison avec les segments voisins. In Debysser, J., Le Pichon, X., and Montadert, L. (Ed.), Histoire Structurale du Golfe de Gascogne (Vol. 1): Paris (Technip), pp. 1-68.

Bard, J. P., Capdevila, R., Matte, P., and Ribeiro, A., 1973. Geotectonic model for the Iberian Variscan orogen. Nat. Phys. Sci., 241: $50-52$.

Bard, J. P., and Moine, B., 1977. Variations géochimiques et affinités tholéitiques abyssales des orthoamphibolites d'Acebuches dans la ceinture métamorphique de basse pression d'Aracena (Huelva), Espagne. Proc. Seme Reunion Ann. Sci. Terre (Rennes).

Belt, E. S. 1968. Post-Acadian rifts and related facies, eastern Canada. In Zen, E-an (Ed.), Studies in Appalachian Geology-Northern and Maritime. New York (Interscience), pp. 95-113.

Blackwood, R. F., and Kennedy, M. J., 1975. The Dover fault: western boundary of the Avalon zone in northeastern Newfoundland. Can. J. Earth Sci., 12(2):320-325.

Blackwood, R. F., and O'Driscoll, C. F., 1976. The Gauder-Avalon zone boundary in southeastern Newfoundland. Can. J. Earth Sci., 13(8):1155-1159.

Blyth, F. G. H., 1957. The Lustleigh Fault in northeast Dartmoor granite. Quart. J. Geol. Soc. London, 118:435-453.

Bott, M. H. P., Day, A. A., and Masson-Smith, D., 1958. The geological interpretation of gravity and magnetic surveys in Devon and Cornwall. Philos. Trans. R. Soc. London Ser. A, 251:161-191.

Butel, P., and Ters, M., 1952. Géologie de l'île de Ré. Bull. Serv. Carte Geol. Fr., 234:540-576.

Carey, S. W., 1958. A tectonic approach to continental drift. Proc. Symposium on Continental Drift (Univ. Tasmania, Hobart), pp. 177-209.

Carvalho, D., 1972. The metallogenic consequences of plate tectonics and the upper Paleozoic evolution of southern Portugal. Estudos Notas e Trabalhos do Serviços de Fomento Mineiro, 20:297-320.

Chapman, C. A., 1962. Bay-of-Maine igneous complex. Geol. Soc. Am. Bull., 5:883-888.

Chauris, L., 1969. Sur un important accident structural dans le nordouest de l'armorique. Compt. Rend., 268:2859-2861.

Choubert, B., 1935. Recherches sur la génèse des chaînes paléozoiques et anté-cambriennes. Rev. Geogr. Phys. Geol. Dynam., 8:5-50.

Choukroune, P., Le Pichon, X., Seguret, M., and Sibuet, J. C., 1973. Bay of Biscay and Pyrenees. Earth Planet. Sci. Lett., 13:110-118.

Cogné, J., 1960. Schistes cristallins et granites en Bretagne méridionale, le domaine de l'anticlinal de Cornouaille. Mémoires pour servir á l'explication de la carte géologique détaillée de la France: Paris (Imprimerie Nationale).
1971. Le Massif armoricain, et sa place dans la structure des socles ouest-européens; l'arc hercynien ibéro-armoricain. In Debysser, J., Le Pichon, X., and Montadert, L. (Eds.), Histoire Structurale du Golfe de Gascogne (Vol. 1): Paris (Technip), pp. 1-23. 1974. Le Massif Armoricain (Géologie de la France) (Vol. 1): Paris (Douin), pp. 105-161.

, 1977. Le chaîne hercynienne ouest-européenne correspondelle à un orogéne par collision? Propositions pour une interprétation géodynamique globale. CNRS Int. Symp., 268:111-129.

Cutt, B. J., and Laving, J. G., 1977. Tectonic elements and geologic history of the south Labrador and Newfoundland continental shelf, eastern Canada. Bull. Can. Petrol. Geol., 25:1037-1058.

Day, G. A., and Williams, C. A., 1970. Gravity compilation in the N. E. Atlantic and interpretation of gravity in the Celtic Sea. Earth Planet. Sci. Lett., 8:205-213.

Dearman, W. R., 1963. Wrench-faulting in Cornwall and South Devon. Proc. Geol. Assoc., 74:265-287.

De Charpal, O., Guennoc, P., Montadert, L., and Roberts, D. G., 1978. Rifting crustal attenuation and subsidence in the Bay of Biscay. Nature, 275:706-711.

Den Tex, E., and Floor, P., 1972. A synopsis of the geology of western Galicia. In Debysser, J., Le Pichon, X., and Montadert, L. (Eds.), Histoire Structurale du Golfe de Gascogne (Vol. 1): Paris (Technip), pp. 1-14.

Durand, S., 1960. Le tertiaire de Bretagne. Mem. Soc. Geol. Mineral. Bretagne, 12.

Gates, O., 1969. Lower Silurian-lower Devonian volcanic rocks of New England coast and southern New Brunswick. In Kay, M. (Ed.), North Atlantic Geology and Continental Drift. Mem. Am. Assoc. Petrol. Geol., 12:484-503.

Gaudette, H. E., 1980. Zircon isotopic age from the Union ultramafic complex, Maine. Can. J. Earth Sci., 18:405-409.

Gerard, J. P., 1979. Étude géologique de la mer Malin (Plateau continental nord-Irlandais) [Ph. D. thesis]. University of Rennes.

Gerard, J. P., and Boillot, G., 1977. Geology of the North Irish continental shelf. Mar. Geol. 23:1-9.

Grant, A. C., 1972. The continental margin off Labrador and eastern Newfoundland-morphology and geology. Can. J. Earth Sci., 9: $1394-1430$

1973. Geological and geophysical results bearing upon the structural history of the Flemish Cap region. In Hood, P. J. (Ed.), Earth Science Symposium on Offshore Eastern Canada. Pap. Geol. Surv. Can., 71-23:373-388.

, 1975. Structural modes of the western margin of the Labrador Sea. In van der Linden, M., and Wade, J. A. (Eds.), Offshore Geology of Eastern Canada (Vol. 2). Pap. Geol. Surv. Can., 74-30: 217-231.

Groupe Galice, 1976. Schéma structural des bancs de Galice, de Vigo et de Porto. Proc. 4eme Reunion Ann. Sci. Terre (Paris).

Guennoc, P., 1978. Structure et évolution géologique de la pente continentale d'un secteur de l'Atlantique nord-est: de la terrasse de Meriadzec à l'éperon de Goban [thesis]. University of Brest.

Hanmer, S., 1981. Tectonic significance of the northeastern Gander Zone, Newfoundland: An Acadian ductile shear zone. Can. J. Earth Sci., 18:120-135.

Haworth, R. T., 1974. Paleozoic continental collision in the northern Appalachians in light of gravity and magnetic data in the Gulf of St. Lawrence. Offshore geology of eastern Canada. Pap. Geol. Surv. Can., 74-30:1-10.

1975. The development of Atlantic Canada as a result of continental collision. Evidence from offshore gravity and magnetic data. In Yorath, C. J., Parker, E. R., and Glass, D. J. (Eds.), Canada's Continental Margins and Offshore Petroleum Exploration. Mem. Can. Soc. Petrol. Geol., 4:59-77.

1977. The continental crust northeast of Newfoundland and its ancestral relationship to the Charlie Fracture Zone. Nature, 266: 246-249.

Haworth, R. T., Grant, A. C., and Folinsbee, R. A., 1976. Geology of the continental shelf off southeastern Labrador. Pap. Geol. Surv. Can., 76-1:61-70.

Haworth, R. T., and Jacobi, R. D., 1983. Geophysical correlations between the geological zonation of Newfoundland and the British 
Isles. In Hatcher, R. D., Zietz, I., and Williams, H. (Eds.), Tectonics and Geophysics of Mountain Chains. Spec. Pap. Geol. Soc. Am., 158:25-32.

Haworth, R. T., and Lefort, J. P., 1979. Geophysical evidence for the extent of the Avalon Zone in Atlantic Canada. Can. J. Earth Sci., $16: 552-567$

Haworth, R. T., and McIntyre, J. B., 1975. The gravity and magnetic field of Atlantic offshore Canada. Pap. Geol. Surv. Can., 75-9: 1-22. 1976. The gravity and magnetic fields of Atlantic offshore Canada. Mar. Sci. Pap., 16. Also Pap. Geol. Surv. Can., 75-9. 1977. The gravity and magnetic fields of the Gulf of St. Lawrence, Canada. Pap. Geol. Surv. Can., 75-42.

Haworth, R. T., Poole, W. H., Grant, A. C., and Sandford, B. V., 1976. Marine geoscience survey northeast of Newfoundland. Pap. Geol. Surv. Can., 76-1A:7-15.

Henri, J. L., Nion, J., Paris, F., and Thadeu, D., 1973. Chitinozoaires, Ostracodes et Trilobites, de l'Ordovicien du Portugal et du Massif Armoricain. Essai du comparaison et signification paléogéographique. Com. Serv, Geol. Portugal, 57:303-345.

Horn, R., Munck, F., and Muraour, P., 1974. Quelques remarques sur la tectonique du socle sous la plateforme continentale atlantique d'après le magnétisme. Coll. Int. Exploit. Oceans (Bordeaux), 128:1-6.

Hughes, C. J., and Bruckner, W. D., 1971. Late Precambrian rocks of eastern Avalon Peninsula, Newfoundland-a volcanic island complex. Can. J. Earth Sci., 8:899-915.

Hydrographic Department, U. K. Department of Defence, 1973. Gravityfree air anomalies, quarter million plotting sheet, maps 016-14 GC, 015-15 GC, and 016-20 G5.

Jacobi, R., and Kristoffersen, Y., 1976. Geophysical and geological trends on the continental shelf off northeastern Newfoundland. Can. J. Earth Sci., 13:1039-1051.

Jaeger, J. L., 1967. Un alignement d'anomalies lègéres coincident avec des bassins tertiaires en Bretagne. Mem. Bur. Rech. Geol. Min., 52:89-102.

Kane, M. F., Yellin, M. J., Bell, K. G., and Zietz, I., 1972. Gravity and magnetic evidence of lithology and structures in the Gulf of Maine region. Prof. Pap. U.S. Geol. Surv., 726B:1-22.

Kay, M., 1969. Continental drift in the North Atlantic Ocean. North Atlantic geology and continental drift. Mem. Am. Assoc. Petrol. Geol., 12:965-973.

Keen, C. E., and Hyndman, R. D., 1979. Geophysical review of the continental margins of eastern and western Canada. Can. J. Earth Sci., 16:712-747.

Kennedy, M. J., 1976. Southeastern margin of the northeastern Appalachians: Jate Precambrian orogeny on a continental margin. Geol. Soc. Am. Bull., 87:1317-1325.

Keppie, J. D., 1977. Tectonics of southern Nova Scotia. Pap. Nova Scotia Dept. Mines, 77-1:1-34.

King, A. F., 1977. Subdivision and paleogeography of late Precambrian and early Paleozoic rocks of the Avalon Peninsula, Newfoundland (Abstract). Geol. Soc. Am. Abstracts with Programs, 9:284.

King, L. H., and MacLean, B., 1970. Continuous seismic-reflection study of Orpheus gravity anomaly. Am. Assoc. Petrol. Geol. Bull., 54:2007-2031.

1976. Geology of the Scotian Shelf and adjacent areas. Mar. Sci. Pap., 7. Also Pap. Geol. Surv. Can., 74-31.

Kranck, E. H., 1947. Indication of movements of the earth crust along the coast of Newfoundland-Labrador. Finland Geol. Bull., 140: 89-96.

Lamboy, M., 1976. Géologie marine et sous-marine du plateau continental au Nord-ouest de l'Espagne [thesis]. Université de Rouen.

Lefort, J. P., 1973. La zonale Biscaye-Labrador: Mise en évidence de cisail-lements dextres antérieurs à l'ouverture de l'Atlantique Nord. Mar. Geol., 14:M33-M38.

1975. Le socle péri-armoricain: étude géologique et géophysique du socle submergé à l'Ouest de la France [thesis]. University of Rennes.

1979a. Iberian-Armorican arc and Hercynian orogeny in western Europe. Geology, 7:384-388.

1979b. Failles de socle et directions transformantes en Atlantique Nord. Proc. 7eme Reunion Ann. Sci. Terre (Lyon).
1980. Un "fit" structural de l'Atlantique Nord: arguments géologiques pour corréler les marqueurs géophysiques reconnus sur les deux marges. Mar. Geol., 37:355-369.

1983. A new criterion to correlate the Acadian and Hercynian orogenies of western Europe and eastern America. In Hatcher, R. D., Williams, H., and Zietz, I. (Eds.), Tectonics and Geophysics of Mountain Chains. Mem. Geol. Soc. Am., 158:3-18.

Lefort, J. P., Alverhinho-Dias, J., Monteiro, H., and Ribeiro, A., 1981. Les structures profondes du socle Portugais à l'ouest de la Faille Porto-Badajoz. Comm. Serv. Geol. Portugal, 67:57-63.

Lefort, J. P., Audren, C., Jegouzo, P., Max, M. D., Grant, P., and Rattey, P., 1982. Disposition of structures in the South of Brittany (France). Belt of high pressure metamorphism. In Blanchard, J., Mair, J., and Morrison, I. (Eds.), Proc. Sixth Int. Sci. Symp. World Underwater Federation (Edinburgh).

Lefort, J. P., and Haworth, R. T., 1978. Geophysical study of basement fractures on the western European and eastern Canadian shelves: transatlantic correlations and late Hercynian movements. Can. J. Earth Sci., 15:397-404.

1979. The age and origin of the deepest correlative structures recognized off Canada and Europe. Tectonophysics, 59:139-150. 1981. Geophysical correlation between basement features in North Africa and eastern New England: their control over North Atlantic structural evolution. Bull. Soc. Geol. Mineral. Bretagne, Ser. C, 13:103-116.

in press. Geophysical evidence for the extension of the Hercynian Front onto the Canadian continental margin: geodynamic and paleogeographic consequences. J. Geol. Soc. London.

Lefort, J. P., and Max, M. D., in press. Development of the Porcupine Seabight: the direct relationship between early oceanic and continental structures. J. Geol. Soc. London.

Lefort, J. P., and Segoufin, J., 1978. Etude géologique de quelques structures magnétiques reconnues dans le socle péri-armoricain. Bull. Soc. Geol. Fr., 20:185-192.

Lefort, J. P., and Van der Voo, R., 1981. A kinematic model for the collision and complete suturing between Gondwanaland and Laurussia in the Carboniferous. J. Geol., 89:537-550.

Le Pichon, X., Sibuet, J. C., and Francheteau, J., 1977. The fit of continents around the North Atlantic Ocean. Tectonophysics, 38: 169-209.

Leutwein, F., Sonet, J., and Zimmermann, J. L., 1972. Dykes basiques du Massif Armoricain septentrional. Comp. Rend., 275:1327-1330.

Lilly, H. D., 1966. Late Precambrian and Appalachian tectonics in the light of submarine exploration on the Great Bank of Newfoundland and in the Gulf of St. Lawrence-preliminary views. Am. J. Sci., 264:569-574.

Lötze, F., 1956. Ueber sardische Bewegingen in Spanien und ihre Beziehugen zur assyntischen Faltung. In Stille, H., and Enke, F. (Eds.), Stille Festschr. (Stuttgart), pp. 128-139.

McKerrow, W. S., and Cocks, L. R. M., 1977. The location of the Iapetus suture in Newfoundland. Can. J. Earth Sci., 14:488-495.

McKerow, W. S., and Ziegler, A. M., 1972. Paleozoic oceans. Nature Phys. Sci., 240:92-94.

Matte, P., 1968. La structure de la virgation hercynienne de Galice (Espagne) [thesis]. Rev. Geogr. Alp., 44.

Matte, P., and Ribeiro, A., 1975. Forme et orientation de l'ellipsoîde de déformation dans la virgation hercynienne de Galice. Relations avec le plissement et hypothèses sur la genèse de l'arc ibéro-armoricain. Comp. Rend., Ser. D, 279:543-545.

Max, M. D., 1978. Tectonic control of offshore sedimentary basins to the north and west of Ireland. J. Petrol. Geol., 1:103-110.

Max, M. D., Inamdar, D. D., and McIntyre, T., 1982. Compilation magnetic map. The Irish continental shelf and adjacent areas. Geol. Surv. Ireland Rept., 82/2.

Max, M. D., and Lefort, J. P., in press. Does the Hercynian Front in Ireland follow a shear zone? J. Geol. Soc. London.

Munha, J., 1979. Blue amphiboles, metamorphic regime and plate tectonic modelling in the Iberian pyrite belt. Contr. Mineral. Petrol., 69:279-289.

Miller, S. A., Roberts, D. G., and Matthews, D. H., 1973. Rocks of Grenville age from Rockall Bank. Nature Phys. Sci., 246. 
Naylor, D., and Sevastopulo, G. D., 1980. Ireland, stratigraphy and paleogeography. In Descourt, J. (Ed.), Geology of European Countries: Paris (Dunod), pp. 338-343.

Osberg, P. H., 1978. Synthesis of the geology of the northeastern Appalachians, U.S.A. Pap. Geol. Surv. Can., 78-13:137-148.

Papezik, V. S., 1972. Late Precambrian ignimbrites in eastern Newfoundland and their tectonic significance. Proc. 24th Int. Geol. Congr. (Montreal), 1:147-152.

Parga, J. R., 1969. Sistema de Fracturas tardihercinicas del Macizo Hesperico. Trabajos del Laboratorio de Geologia de Lage, 37:3-15.

Paris, F., and Robardet, M., 1977. Paléogéographie et relations ibéroarmoricaines au Paléozoîque anté-carbonifère. Bull. Soc. Geol. Fr, XIX(5):1121-1126.

Perroud, H., 1980. Contribution à l'étude paléomagnétique de l'arc ibero-armoricain [thesis]. University of Rennes.

Perroud, H., Bonhommet, N., Desouches, V., and Ribeiro, A., 1982. Preliminary palaeomagnetic results for the upper Devonian Beja Gabbro, southern Portugal. EOS Trans. Am. Geophys. Union, 63.

Poole, W. H., 1976. Plate tectonic evolution of the Canadian Appalachian region. Pap. Geol. Surv. Can., 76-1B:113-126.

Quinquis, H., 1980. Schistes bleus et déformation progressive: l'exemple de l'île de Groix (Massif Armoricain) [thesis]. University of Rennes.

Rankin, D. W., 1976. Appalachian salients and recesses: late Precambrian continental breakup and the opening of the lapetus Ocean. J. Geophys. Res., 82:5605-5619.

Riddihough, R. R., and Max, M. D., 1976. A geological framework for the continental margin to the west of Ireland. Geol. J., 11: 109-120.

Ries, A. C., and Schackleton, F. R. S., 1976. Patterns of strain variation in arcuate fold belts. Philos. Trans. R. Soc. London Ser. A, 283:281-288.

Roberts, D. G., 1970. Recent geophysical studies on the Rockall Plateau and adjacent areas. Proc. Geol. Soc. London, 1662:87-92.

1975. Marine geology of the Rockall Plateau and Trough. Philos. Trans. R. Soc. London Ser. A, 278:447-501.

Roberts, D. G., Masson, D. G., and Miles, P. R., 1981. Age and structure of the southern Rockall Trough: new evidence. Earth Planet. Sci. Lett., 52:114-128.

Roberts, D. G., Matthews, D. H., and Eden, R. E., 1972. Metamorphic rocks from the southern end of Rockall Bank. Nature Phys. Sci., 244:21-23.

Schenk, P., 1971. Southeastern Atlantic Canada, northwestern Africa and continental drift. Can. J. Earth Sci., 8:1218-1251.

Scrutton, R. A., 1972. The crustal structure of Rockall Plateau microcontinent. Geophys. J. R. Astron. Soc., 27:259-275.

Sibuet, J. C., 1972. Histoire structurale du Golfe de Gascogne [thesis]. University of Strasbourg.
Srivastava, S. P., 1978. Evolution of the Labrador Sea and its bearing on the early evolution of the North Atlantic. Geophys. J. R. Astron. Soc., 52:313-357.

Stillman, C. J., 1979. Caledonide volcanism in Ireland. The caledonides in the USA. In Wones, D. (Ed.), IGCP Project 27: Caledonide Orogen: Blacksburg (Virginia Polytechnic Institute and State University), Mem. 2:279-284.

Stockwell, C. H., McGlynn, J. C., Emslie, R. F., Sanford, B. V., Norris, A. N., et al., 1965. Geology of the Canadian Shield. In Douglas, R. J. W. (Ed.), Geology and Economic Minerals of Canada: Ottawa (Geol. Surv. Can.), pp. 43-150.

Tamain, G., 1978. L'évolution calédono-varisque des Hespérides. Pap. Geol. Surv. Can., 78-10:183-241.

Thomas, M. D., 1974. Gravity Map Series: Ottawa (Dept. Energy, Mines and Resources).

Van Breemen, O., Bowes, D. R., and Phillips, N. E. A., 1976. Evidence for basement of late Precambrian age in the Caledonides of western Ireland. Geology, 4:499-501.

van der Linden, W. J. M., and Srivastava, S. P., 1975. The crustal structure of the continental margin off central Labrador. In van der Linden, W. J. M., and Wade, J. A. (Eds.), Offshore Geology of Eastern Canada. Pap. Geol. Surv. Can., 74-40:233-245.

Vegas, R., 1978. Sedimentation and tectonism in the Iberian Massif prior to the Hercynian deformation (late Precambrian to Silurian times). In Julivert, M., Capdevila, R., Den Tex, E., Matte, P., and Ribeiro, A. (Eds.), Livre Jubilaire du Professeur Parga-Pondal. Geologia de la Parte Norte del Macizo Iberico. Cuaderno del Seminario de Estudios Ceramicos de Sargadelos, 27:271-285.

Vegas, R., Munoz, M., 1976. El contacto entre las zonas surportuguesa y Ossa Morena en SW Espana. Una nueva interpretacion. Com. Serv. Geol. Portugal, 60:31-51.

Vigneresse, J. L., 1978. Gravimétrie et granites Armoricains [thesis]. University of Rennes.

Vogt, P. R., and Avery, O. E., 1974. Detailed magnetic surveys in the northeast Atlantic and Labrador Sea. J. Geophys. Res., 79:363-389.

Webb, G. W., 1969. Paleozoic wrench faults in Canadian Appalachians. In Kay, M. (Ed.), North Atlantic-Geology and Continental Drift. Mem. Am. Assoc. Petrol. Geol., 12:759-785.

Williams, H., 1979. Appalachian Orogen in Canada. Can. J. Earth Sci., 16:792-807.

Williams, H., and King, A. F., 1976. Southern Avalon Peninsula, Newfoundland: Trepassy map area (1K). Geol. Surv. Can.

Date of Initial Receipt: June 13, 1983

Date of Acceptance: June 15, 1983 